medRxiv preprint doi: https://doi.org/10.1101/2021.07.06.21260112; this version posted July 8, 2021. The copyright holder for this preprint (which was not certified by peer review) is the author/funder, who has granted medRxiv a license to display the preprint in perpetuity. It is made available under a CC-BY-NC 4.0 International license .

\title{
COVID-19 Due to Wild-Type SARS-CoV-2 More Prevalent in Adolescents and Youth than in Older Adults Based on 19 US States in Fall 2020 Prior to Vaccine Availability
}

\author{
Barbara Rumain $^{\mathrm{a}, \mathrm{b}}, \mathrm{PhD}$, Moshe Schneiderman ${ }^{\mathrm{c}}, \mathrm{BA}$, Allan Geliebter ${ }^{\mathrm{d}}, \mathrm{PhD}$
}

\author{
Affiliations: \\ ${ }^{a}$ Department of Pediatrics, New York Medical College, Valhalla, New York, USA \\ ${ }^{\mathrm{b}}$ Department of Psychology, Touro College \& University System, New York, N.Y., USA \\ ${ }^{c}$ SUNY Downstate College of Medicine, Brooklyn, New York, USA \\ ${ }^{\mathrm{d}}$ Department of Psychiatry, Icahn School of Medicine at Mount Sinai, New York, N.Y., USA
}

Address correspondence to: Barbara Rumain, Ph.D., Department of Pediatrics, New York Medical College, 40 Sunshine Cottage Road, Valhalla, New York 10595;

email: barbara.rumain@touro.edu

Running Title: COVID-19 Due to Wild-Type SARS-CoV-2

\begin{abstract}
PURPOSE: In a prior study, we examined data from six US states during Summer 2020, and found that prevalence of COVID-19 for adolescents and youth was significantly greater than for older adults $(\mathrm{p}<.00001)$ as was a prevalence-related measure: Number of cases observed $\div$ Number of cases expected ( $\mathrm{p}<.005)$. We now extended our study to more states in Fall 2020 to confirm the prevalence relationships we found previously. Vaccines were still not available as of Fall 2020. Presumably, the SARS-CoV-2 strain circulating at the time was the wild-type lineage since no variants were reported in the US until the end of December 2020.

METHODS: We examined data from 19 U.S. states experiencing surges in cases to determine prevalence of COVID-19, and a prevalence-related measure: [Number of cases observed in a given age group $] \div$ [Number of cases expected in the age group based on population demographics].

RESULTS: In 16 of the 19 states, we found that: (1) prevalence of COVID-19 for adolescents and youth was significantly greater than for older adults ( $p$-values ranged from $\mathrm{p}<0.00001$ to $p=$ 0.0175 ; (2) the ratio of cases observed to cases expected was significantly greater in adolescents and youth than in older adults ( $p$-values ranging from $p<0.00001$ to $p=0.004$ ).

CONCLUSIONS: Our results are consistent with our previous study in Summer 2020. The finding of lower prevalence in older adults cannot be attributed to access to vaccination since our data are from Fall 2020 when vaccinations were not yet available. Our findings with the SARSCoV-2 wild-type strain are consistent with the findings currently being reported in the UK for the delta variant. In both studies, prevalence in adolescents and youth exceeded that in older adults. The UK findings are more pronounced perhaps because that study transpired following months of vaccinations of older adults whereas ours occurred before vaccinations were available.
\end{abstract}


medRxiv preprint doi: https://doi.org/10.1101/2021.07.06.21260112; this version posted July 8, 2021. The copyright holder for this preprint (which was not certified by peer review) is the author/funder, who has granted medRxiv a license to display the preprint in perpetuity.

It is made available under a CC-BY-NC 4.0 International license.

\section{INTRODUCTION}

The susceptibility of adolescents (10-19) and youth (15-24) to COVID-19 has been a matter

47 of controversy. In the very early studies conducted in China, Dong et al. [1], Lu et al. [2], and

48 Bi et al. [3] reported that adolescents were susceptible, with Bi et al. [3] reporting that the rate of

49 infection across all age groups was similar. However, Zhang et al. [4], in a study in Hunan

50 province, China, concluded that older adults were the most susceptible, those in the first half of

51 adolescence least susceptible, and youth (15-24) intermediate in susceptibility. Geliebter,

52 Rumain \& Schneiderman [5] attempted to replicate Zhang et al.'s statistical analyses but

53 obtained results in line with those of Bi et al., indicating a similar infection rate across the age

54 groups. Nevertheless, other data from Europe also indicated that adolescents were less

55 susceptible than adults (Kuchar et al. in Warsaw [6]; de Lusignan et al. [7] in England). Also,

56 Viner et al. [8], after a meta-analysis of 32 studies, concluded that "children and adolescents

57 younger than 20 years had $44 \%$ lower odds of secondary infection with SARS-CoV-2 as

compared with adults 20 years and older." Subsequently, a mathematical model by Eggo and her

colleagues [9], based on data from China, Italy, Japan, Singapore, Canada and South Korea,

60 estimated that the susceptibility of adolescents $10-19$-year-olds (mean $=.38$ ) was less than half

61 that of older adults, ages $60+($ mean $=.81)$, but that youth in their early 20 s had a susceptibility

62 almost equal to that of older adults. However, no U.S. data were included in their model.

We [10] therefore decided to examine data from the U.S. We calculated the prevalence in

64 adolescents and youth compared to that of older adults in the U.S. in the summer of 2020. We

analyzed the health department data from six US states that were experiencing surges in cases.

In all six states, we found that: (1) prevalence of COVID-19 for adolescents and youth was

67 significantly greater than for older adults, $\mathrm{p}<.00001$, as was $(2)$ the ratio of observed to 
medRxiv preprint doi: https://doi.org/10.1101/2021.07.06.21260112; this version posted July 8, 2021. The copyright holder for this preprint (which was not certified by peer review) is the author/funder, who has granted medRxiv a license to display the preprint in perpetuity. It is made available under a CC-BY-NC 4.0 International license .

expected cases, $\mathrm{p}<.005$. Vaccines were not yet available during the time of our study, and therefore, our findings were not an artifact of older adults being vaccinated first.

One limitation in our prior study was that it was based on data from only six U.S. states. The purpose of the present study was to investigate the prevalence of COVID-19 in adolescents and youth compared to that in older adults, in 19 states that met certain criteria. We also wanted to confirm the relationships we found during Summer 2020 in the Fall of 2020, when states were experiencing new surges in cases. Vaccines were still not available as of Fall 2020.

\section{METHODS}

There were two criteria for inclusion of states in our study sample:

1. The state experienced a surge during Fall 2020, defined as follows: After at least a 1month plateau in the 7-day average of daily number of new cases, there was a dramatic increase of at least $75 \%$ from the plateau 2-3 months prior, which lasted at least one month, as reported for the states in the New York Times "COVID Map and Case Count" [11]. As an example, for Colorado, the case data are from October $22^{\text {nd }}$ when there was a surge. On that day, the 7-day average number of daily new cases was 1,171 . Sixty days prior on August $22^{\text {nd }}$, the 7 -day daily average was 296 , representing a $300 \%$ increase over August $22^{\text {nd }}$, and the surge was at least one month in duration. For the months of June, July, and through August 21, the 7-day daily average of new cases had plateaued at 200500 cases per day. Another example is Wisconsin, where the case data are from October $23^{\text {rd }}$. On that day the7-day daily average was 3,547 . The surge lasted at least a month from October $23^{\text {rd }}$, with November $23^{\text {rd }}$ reporting a 7-day average of daily new cases at 6,436 . Sixty days prior, on August $23^{\text {rd }}$, the 7-day daily average of new cases was 708 . Thus, there was $>400 \%$ increase in the 7 -day daily average. Prior to that, for the months 
medRxiv preprint doi: https://doi.org/10.1101/2021.07.06.21260112; this version posted July 8, 2021. The copyright holder for this preprint (which was not certified by peer review) is the author/funder, who has granted medRxiv a license to display the preprint in perpetuity. It is made available under a CC-BY-NC 4.0 International license .

of June, July and August, the 7-day daily average of new cases had reached a plateau, fluctuating from 300-962 cases per day. Even from the maximum of 962, the 3,547 cases on October $23^{\text {rd }}$ represented a $268 \%$ increase.

2. The pediatric data were tabulated within distinct age brackets, not amalgamated. California lumped all child data 0-17 years of age together, and could not be included as children under age 10 are excluded. Massachusetts lumped children 0-19 together, as did Arizona. We therefore considered the following 19 states: Alabama, Alaska, Colorado, South Carolina, New Mexico, Michigan, Montana, Wisconsin, Rhode Island, South Dakota, Missouri, Oklahoma, North Dakota, Oregon, Nevada, Pennsylvania, Minnesota, Florida, and Tennessee. We accessed online tables containing COVID-19 case data when there was a surge from state Health Department websites, and tables for state population data by age group. Case data were downloaded between October $22^{\text {nd }}$ and December 5 th, at the time each of the states was experiencing a spike in cases. The websites are detailed in S1 Appendix, which includes the relevant tables/figures.

Depending on how the data were tabulated, the case data for the 19 states were either for adolescents (ages 10-19), for youth (ages 15-24), or for adolescents and youth combined. Adolescents: In the following 13 states, data were tabulated by decade, and we examined the 10-19-year age bracket: Alaska, Colorado, New Mexico, Michigan, Wisconsin, Montana, South Dakota, North Dakota, Oregon, Nevada, and Pennsylvania. Tennessee had a similar age bracket of 11-20 years of age. Thus these 13 states provided data on adolescents.

Youth: The four states of Florida, Oklahoma, Rhode Island and Alabama, provided the data on youth. The age brackets for Florida and for Oklahoma were 5-14, and 15-24 ("youth" as defined by the WHO). Therefore, we used only the 15-24-year-olds for both these states. We also 
medRxiv preprint doi: https://doi.org/10.1101/2021.07.06.21260112; this version posted July 8, 2021. The copyright holder for this preprint (which was not certified by peer review) is the author/funder, who has granted medRxiv a license to display the preprint in perpetuity. It is made available under a CC-BY-NC 4.0 International license .

114 115

used the 15-24 age bracket for Rhode Island. For Alabama, cases were reported for 0-4, 5-17 years and for 18-24 years--age bracket demarcations unlike the other states, and we used the 1824 years age bracket, since this is a subset of the "youth" age bracket.

Adolescents and Youth Combined: Minnesota and Missouri provided data on adolescents and youth combined. For both Minnesota and Missouri, we considered the age bracket 10-24-yearolds.

The case data from the Health Department websites was used to compute "Percentage of Cases Observed," calculated as the number of cases in a particular age group divided by the total number of cases for all ages in the state and converted into a percentage. The "Percentage of Cases Expected" was determined based on population demographics: For each age group, it was the percentage of the population the given age group comprises, multiplied by the total number of cases. The population demographic data were obtained from the state websites, listed in S1 Appendix.

We then calculated two measures: 1) Prevalence, and 2) "Percentage of Cases Observed" in a given age group $\div$ "Percentage of Cases Expected" based on population demographics as noted above. For an illustration of how these measures were calculated, see Rumain et al. (2021). Statistics: We performed chi-square calculations to determine whether differences between the adolescent/youth groups and the older adults were significant for the two outcome measures. Significance level was based on 2-tailed $\alpha=.05$.

\section{RESULTS}

In 16 of the 19 states, we found that: (1) prevalence of COVID-19 for adolescents and youth was significantly greater than for older adults, with $p$-values varying from $\mathrm{p}<0.00001$ to $p=$ 0.0175 ; and (2) the ratio of observed number of cases to expected number of cases was 
medRxiv preprint doi: https://doi.org/10.1101/2021.07.06.21260112; this version posted July 8, 2021. The copyright holder for this preprint (which was not certified by peer review) is the author/funder, who has granted medRxiv a license to display the preprint in perpetuity.

It is made available under a CC-BY-NC 4.0 International license .

137 significantly greater in adolescents and youth than in older adults, with $p$-values varying from

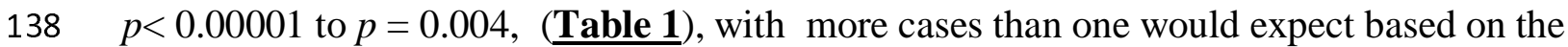

139 demographics of the populations. The three states that did not follow the general pattern were:

140 South Dakota, Michigan and Pennsylvania.

Table 1. Prevalence-related Outcome Measures by Developmental Period and Age Bracket in US States Experiencing Spikes in COVID-19 Cases

\begin{tabular}{|c|c|c|c|c|c|}
\hline \multicolumn{6}{|c|}{ Adolescence } \\
\hline & Prevalence & & $\begin{array}{l}\chi^{2} \\
\text { p-value }\end{array}$ & Observed $\div$ Expected & $\begin{array}{l}\chi^{2} \\
\text { p-value }\end{array}$ \\
\hline \multicolumn{6}{|c|}{ Alaska-October $312020 *$} \\
\hline 10-19 & $1,811 / 99,499$ & $=1.8 \%$ & \multirow[t]{2}{*}{$\begin{array}{l}\chi^{2}=5.65 \\
p=0.0175\end{array}$} & $1,811 / 2,093$ & \multirow[t]{2}{*}{$\begin{array}{l}\chi^{2}=10.9 \\
p=0.00095\end{array}$} \\
\hline 60+ & $2,330 / 142,099$ & $=1.6 \%$ & & $2,330 / 2,978$ & \\
\hline \multicolumn{6}{|c|}{ Colorado - October 222020} \\
\hline 10-19 & $9,890 / 731,951$ & $=1.35 \%$ & \multirow[t]{2}{*}{$\begin{array}{c}\chi 2=12.6 \\
p=0.000387\end{array}$} & $9,890 / 11,630$ & \multirow[t]{2}{*}{$\begin{array}{l}\chi 2=8.3 \\
p=.004\end{array}$} \\
\hline 60+ & $15,476 / 1,199,263$ & $=1.29 \%$ & & $15,476 / 19139$ & \\
\hline \multicolumn{6}{|c|}{ Michigan - November 172020} \\
\hline 10-19 & $37,393 / 1,267,877$ & $=2.9 \%$ & \multirow[t]{2}{*}{$\begin{array}{l}\chi^{2}=1910.1 \\
\mathrm{p}<.00001\end{array}$} & $37,393 / 49,530$ & \multirow[t]{2}{*}{$\begin{array}{l}\chi^{2}=1102.6 \\
p<0.00001\end{array}$} \\
\hline 60+ & $92,591 / 2,393,510$ & $=3.9 \%$ & & $92,591 / 93,209$ & \\
\hline \multicolumn{6}{|c|}{ Montana - October 232020} \\
\hline 10-19 & $3,001 / 137,796$ & $=2.2 \%$ & \multirow[t]{2}{*}{$\begin{array}{l}\chi_{2}^{2}=17.8 \\
p=.000024\end{array}$} & $3,001 / 13,394$ & \multirow[t]{2}{*}{$\begin{array}{l}\chi^{2}=14.7 \\
p=0.000124\end{array}$} \\
\hline $60+$ & $5,668 / 286,567$ & $=1.97 \%$ & & $5,668 / 27,834$ & \\
\hline \multicolumn{6}{|c|}{ Nevada-October 302020} \\
\hline 10-19 & $8,727 / 391,347$ & $=2.2 \%$ & \multirow[t]{2}{*}{$\begin{array}{l}\chi^{2}=31.1 \\
p<0.00001\end{array}$} & $8,727 / 12,857$ & \multirow[t]{2}{*}{$\begin{array}{l}\chi 2=29288.5 \\
\mathrm{p}<0.00001\end{array}$} \\
\hline 60+ & $14107 / 683,039$ & $=2.1 \%$ & & $14,107 / 22,373$ & \\
\hline \multicolumn{6}{|c|}{ New Mexico - October 232020} \\
\hline 10-19 & $4,513 / 285,393$ & $=1.6 \%$ & \multirow[t]{2}{*}{$\begin{array}{c}\chi 2=252.6 \\
p<0.00001\end{array}$} & $4,513 / 5,456$ & \multirow[t]{2}{*}{$\begin{array}{l}\chi 2=62.4 \\
p<0.00001\end{array}$} \\
\hline 60+ & $6,726 / 518,073$ & $=1.3 \%$ & & $6,726 / 9,950$ & \\
\hline \multicolumn{6}{|c|}{ North Dakota - October 232020} \\
\hline 10-19 & $4,658 / 97,348$ & $=4.78 \%$ & \multirow[t]{2}{*}{$\begin{array}{l}\chi 2=34.1 \\
p<0.00001\end{array}$} & $4,658 / 4,490$ & \multirow[t]{2}{*}{$\begin{array}{l}\chi 2=18.4 \\
p=0.000018\end{array}$} \\
\hline $60+$ & $7,143 / 167,040$ & $=4.28 \%$ & & $7,143 / 7,718$ & \\
\hline
\end{tabular}


medRxiv preprint doi: https://doi.org/10.1101/2021.07.06.21260112; this version posted July 8, 2021. The copyright holder for this preprint (which was not certified by peer review) is the author/funder, who has granted medRxiv a license to display the preprint in perpetuity.

\begin{tabular}{|c|c|c|c|c|}
\hline & Prevalence & $\begin{array}{l}\chi^{2} \\
\text { p-value }\end{array}$ & Observed $\div$ Expected & $\begin{array}{c}\chi^{2} \\
p-\text {-value }\end{array}$ \\
\hline \multicolumn{5}{|c|}{ Oregon - October 302020} \\
\hline 10-19 & $4,840 / 504,711$ & \multirow[t]{2}{*}{$\begin{array}{c}\chi 2=226.9 \\
p<0.00001\end{array}$} & $4,840 / 5,262$ & \multirow[t]{2}{*}{$\begin{array}{l}\chi^{2}=191.3 \\
p<0.00001\end{array}$} \\
\hline $60+$ & $7,136 / 985,350$ & & 7,136/10,966 & \\
\hline \multicolumn{5}{|c|}{ Pennsylvania - October 302020} \\
\hline 10-19 & $18,319 / 1,568,292=\mathbf{1 . 2 \%}$ & \multirow[t]{2}{*}{$\begin{array}{l}\chi^{2}=1907.5 \\
\mathrm{p}<0.00001\end{array}$} & $18,319 / 25,808$ & \multirow[t]{2}{*}{$\begin{array}{l}\chi^{2}=1116.6 \\
p<0.00001\end{array}$} \\
\hline 60+ & $55,956 / 3,301,963$ & & $55,956 / 53,294$ & \\
\hline \multicolumn{5}{|c|}{ South Carolina - December 52020} \\
\hline 11-20 & $33,151 / 673,843$ & \multirow[t]{2}{*}{$\begin{array}{l}\chi^{2}=675.1 \\
\mathrm{p}<0.00001\end{array}$} & $33,151 / 331,243$ & \multirow[t]{2}{*}{$\begin{array}{l}\chi^{2}=80404.7 \\
\mathrm{p}<0.00001\end{array}$} \\
\hline $61+$ & $49,368 / 1,211,555$ & & $49,368 / 56,047$ & \\
\hline \multicolumn{5}{|c|}{ South Dakota - October 232020} \\
\hline 10-19 & $4,052 / 117,276$ & \multirow[t]{2}{*}{$\begin{array}{l}\chi^{2}=2.2 \\
p=\text { n.s. }\end{array}$} & $4,052 / 5,142$ & \multirow[t]{2}{*}{$\begin{array}{l}\chi 2=14.8 \\
p=0.000118\end{array}$} \\
\hline $60+$ & $7,569 / 225,553$ & & $7,569 / 8,682$ & \\
\hline \multicolumn{5}{|c|}{ Tennessee - November 112020} \\
\hline 11-20 & $38,925 / 855,574$ & \multirow[t]{2}{*}{$\begin{array}{l}\chi 2=2141.8 \\
p<0.00001\end{array}$} & $38,925 / 38,140$ & \multirow[t]{2}{*}{$\begin{array}{l}\chi^{2}=665.7 \\
p<0.00001\end{array}$} \\
\hline 61+ & $52,404 / 1,577,807$ & & $52,404 / 65,131$ & \\
\hline \multicolumn{5}{|c|}{ Wisconsin-October 232020} \\
\hline 10-19 & $22,857 / 748,773$ & \multirow[t]{2}{*}{$\begin{array}{l}\chi^{2}=776.5 \\
p<0.00001\end{array}$} & $22,857 / 24,572$ & \multirow[t]{2}{*}{$\begin{array}{l}\chi^{2}=412.8 \\
\mathrm{p}<0.00001\end{array}$} \\
\hline $60+$ & $34,286 / 1,428,853$ & & $34,286 / 46,667$ & \\
\hline \multicolumn{5}{|c|}{ Youth } \\
\hline & Prevalence & $\begin{array}{l}\chi^{2} \\
\text { p-value }\end{array}$ & Observed $\div$ Expected & $\begin{array}{l}\chi^{2} \\
\text { p-value }\end{array}$ \\
\hline \multicolumn{5}{|c|}{ Alabama - November 132020} \\
\hline 18-24 & $25,413 / 458,530$ & \multirow[t]{2}{*}{$\begin{array}{l}\chi^{2}=2,712.4 \\
\mathrm{p}<0.00001\end{array}$} & $25,413 / 180,275$ & \multirow[t]{2}{*}{$\begin{array}{l}\chi^{2}=27,572.4 \\
p<0.00001\end{array}$} \\
\hline $65+$ & $30,186 / 854,313$ & & $30,186 / 854,313$ & \\
\hline \multicolumn{5}{|c|}{ Florida - November 122020} \\
\hline 15-24 & $140,515 / 2,555,315$ & \multirow[t]{2}{*}{$\begin{array}{l}\chi 2=28,969.7 \\
p<0.00001\end{array}$} & $\begin{aligned} & 140,515 / 103,030=136 \% \\
&\end{aligned}$ & \multirow[t]{2}{*}{$\begin{array}{l}\chi 2=14,686.4 \\
p<0.00001\end{array}$} \\
\hline $65+$ & $126,647 / 4,465,169$ & & $126,647 / 180,303$ & \\
\hline \multicolumn{5}{|c|}{ Oklahoma- October 222020} \\
\hline 15-24 & $22,499 / 543,700$ & \multirow[t]{2}{*}{$\begin{array}{l}\chi 2=2,350.0 \\
p<0.00001\end{array}$} & $22,499 / 15,298$ & \multirow[t]{2}{*}{$\begin{array}{l}\chi^{2}=1186.9 \\
p<0.00001\end{array}$} \\
\hline $65+$ & $15,853 / 635,222$ & & $15,853 / 18,110$ & \\
\hline \multicolumn{5}{|c|}{ Rhode Island - October 242020} \\
\hline 15-24 & $4,696 / 145,880$ & $\begin{array}{c}\chi^{2}=104.8 \\
p<0.00001\end{array}$ & $4,696 / 3,856$ & $\begin{array}{l}\chi^{2}=65.1 \\
p<0.00001\end{array}$ \\
\hline 60+ & $7,017 / 265,058$ & & $7,017 / 7,190$ & \\
\hline
\end{tabular}


medRxiv preprint doi: https://doi.org/10.1101/2021.07.06.21260112; this version posted July 8, 2021. The copyright holder for this preprint (which was not certified by peer review) is the author/funder, who has granted medRxiv a license to display the preprint in perpetuity. It is made available under a CC-BY-NC 4.0 International license.

\section{Adolescence Plus Youth}

\begin{tabular}{|c|c|c|c|c|}
\hline & Prevalence & $\begin{array}{l}\chi^{2} \\
\text { p-value }\end{array}$ & Observed $\div$ Expected & $\begin{array}{l}\chi^{2} \\
\text { p-value }\end{array}$ \\
\hline \multicolumn{5}{|c|}{ Minnesota - October 232020} \\
\hline $10-24$ & $32,186 / 1,081,469$ & \multirow[t]{2}{*}{$\begin{array}{l}\chi 2=3097.2 \\
p<0.00001\end{array}$} & $32,186 / 24,934$ & \multirow[t]{2}{*}{$\begin{array}{c}\chi^{2}=1588.2 \\
\mathrm{p}<0.00001\end{array}$} \\
\hline $65+$ & $16,017 / 921,491$ & & $16,017 / 21,168$ & \\
\hline \multicolumn{5}{|c|}{ Missouri - October 232020} \\
\hline $10-24$ & $28,634 / 1,192,555$ & \multirow[t]{2}{*}{$\begin{array}{l}\chi^{2}=725.7 \\
p<0.00001\end{array}$} & $28,634 / 23,097$ & \multirow[t]{2}{*}{$\begin{array}{l}\chi^{2}=458.1 \\
\mathrm{p}<0.00001\end{array}$} \\
\hline $65+$ & $19,278 / 1,033,964$ & & $19,278 / 20,691$ & \\
\hline
\end{tabular}

Chi-square statistic was used to compare age brackets within each state;

*The date on which the cumulative data was gathered.

We now consider each developmental period separately: Adolescence, Youth, and Adolescence plus Youth Combined.

Adolescence (10-19-year-olds): Data from 13 States: Alaska, Colorado, Michigan, Montana, Nevada, New Mexico, North Dakota, Oregon, Pennsylvania, South Carolina, South Dakota,

\section{Tennessee and Wisconsin}

Prevalence. The prevalence in adolescents was significantly greater than that in older adults in 10 of the 13 states (Alaska, $p=.02$; Colorado, $p=0.004$; Montana, $p=0.0002$; Nevada, New Mexico, North Dakota, Oregon, South Carolina, Tennessee, and Wisconsin, $\mathrm{p}<0.00001)$. For South Dakota, there was no significant difference between the adolescents and older adults. For Michigan and Pennsylvania, the pattern was reversed with the prevalence in older adults being significantly higher than that in adolescents $(\mathrm{p}<0.00001)$.

Proportion of cases observed to cases expected. The ratio of the number of cases observed to the number of cases expected based on population demographics, was significantly greater for adolescents than for older adults for 10 of the 13 states: Alaska, $\mathrm{p}=0.00095$; Colorado, $\mathrm{p}=$ 0.004; Montana, $\mathrm{p}=0.000124$; North Dakota, $\mathrm{p}=0.00002$; Nevada, New Mexico, Oregon, South Carolina, Tennessee and Wisconsin, all $\mathrm{p}<0.00001$. For Michigan, Pennsylvania, and South 
medRxiv preprint doi: https://doi.org/10.1101/2021.07.06.21260112; this version posted July 8, 2021. The copyright holder for this preprint (which was not certified by peer review) is the author/funder, who has granted medRxiv a license to display the preprint in perpetuity. It is made available under a CC-BY-NC 4.0 International license.

Dakota, the pattern was reversed with the proportion of cases observed to cases expected being significantly greater in older adults than in adolescents (for the former two states, $\mathrm{p}<0.00001$, and for the latter one, $\mathrm{p}=0.000118$ ).

\section{Youth (15-24-year-olds): Data from 4 States: Alabama, Florida, Oklahoma, Rhode Island}

Prevalence. In Alabama, the prevalence in youth 18-24-years-old was 157\% that of older adults $(5.5 \%$ vs. $3.5 \%, \mathrm{p}<0.00001)$. In Florida, the prevalence in youth $15-24$ years of age was $196 \%$ that of older adults, $\mathrm{p}<0.00001$; in Oklahoma, it was $164 \%$ that of older adults, $\mathrm{p}<0.00001$, and in Rhode Island, it was $123 \%$ that of older adults, $\mathrm{p}<0.00001$.

Proportion of cases observed to cases expected. In Alabama, the ratio of observed to expected cases was approximately in 18-24-year-olds $150 \%$ that of older adults (150\% vs. 96\%), $\mathrm{p}<0.00001$; in Florida, the ratio in youth was almost $200 \%$ t that of older adults $(136 \%$ v. $70 \%)$, $\mathrm{p}<0.00001$ ). In Oklahoma, the ratio of observed to expected cases for youth was $167 \%$ that of older adults $(147.1 \%$ vs. $87.5 \%), \mathrm{p}<0.00001$. And, in Rhode Island, it was $125 \%$ that of older adults $(121.8 \%$ vs. $97.6 \%), \mathrm{p}<0.00001$.

Adolescence plus Youth Combined (ages 10-24 years-old): Data from 2 States: Minnesota and

\section{Missouri}

In both Minnesota and Missouri, the prevalence of COVID-19 in 10-24-year-olds was significantly greater than it was in older adults, > 65 years $(\mathrm{p}<0.00001)$. Also, in both states, the proportion of observed cases of COVID-19 to expected cases based was significantly greater for the 10-24-year-olds than it was for the older adults, $\mathrm{p}<0.00001$.

In 16 of the 19 states experiencing surges of cases during Fall 2020, the prevalence of COVID-19 was significantly higher in adolescents and youth than it was in older adults, $\mathrm{p}=$ 0.0022 , sign test. 
medRxiv preprint doi: https://doi.org/10.1101/2021.07.06.21260112; this version posted July 8, 2021. The copyright holder for this preprint (which was not certified by peer review) is the author/funder, who has granted medRxiv a license to display the preprint in perpetuity. It is made available under a CC-BY-NC 4.0 International license .

\section{DISCUSSION}

In 16 of the 19 states experiencing surges of cases during Fall 2020, we found that (i) the prevalence of COVID-19 was significantly higher in adolescents and youth than in older adults, and (ii) similarly the ratio of observed cases of COVID-19 to expected cases based on population demographics was significantly greater $(\mathrm{p}<0.00001)$. Our data is presumably on the original wild type SARS-CoV-2 strain (i.e., the strain with no major mutations) since as of October and November 2020, there were no reports of variants in the US: The first variant reported in the US, the B.1.1.7, was reported at the end of December 2020 [12]. All the data are from October November 2020 except for South Carolina which is from December 5, 2020 — all before the report of any variants in the U.S. Moreover, our findings of lower prevalence in older adults cannot be attributed to access to vaccination since our data are from Fall 2020 when vaccinations were not yet available. A possible reason for our findings is that adolescents have more contacts than adults [13], and another factor, is that older adults, feeling vulnerable, may be more likely to adhere to masking and social distancing, which adolescents/youth may disregard. Both these factors are likely operative.

Our findings in the six U.S. states differ from those of Zhang et al. in China, who found that the infection rate in older adults, ages 65+, exceeded that in adolescents and youth, and from those of $\mathrm{Wu}$ et al. [14], who found that of 44,672 confirmed cases of COVID in mainland China, only $1 \%$ were in adolescents ages $10-19$ years of age. Out findings also contradict Davies et al.'s model that estimates 10-19-year-olds' susceptibility to be half that of older adults. The reason for the discrepancy could be these earlier studies were conducted when schools were closed, which reduced the number of contacts by adolescents and youth, and thus the number of cases. Moreover, testing was not readily available early on in the pandemic, and adolescents tend to 
medRxiv preprint doi: https://doi.org/10.1101/2021.07.06.21260112; this version posted July 8, 2021. The copyright holder for this preprint (which was not certified by peer review) is the author/funder, who has granted medRxiv a license to display the preprint in perpetuity. It is made available under a CC-BY-NC 4.0 International license .

have milder cases of COVID-19 that could have been missed without the availability of widespread testing. In line with this reasoning is as of April 2, 2020, among 149,082 cases in all age groups for which patient age was known, only 2,572 (1.7\%) of these occurred in children aged $<18$ years, with nearly $60 \%$ of these cases occurring in adolescents $10-17$ years old [15]. Hence at that point, adolescents accounted for just $1 \%$ of the total cases. But by Sept 15, 2020, a month or two before our data was collected, the number of cases in adolescents 10-19 years of age had climbed to 387,000 [16]. And, as of June 24, 2021, the American Academy of Pediatrics reported 4,032,782 total confirmed COVID-19 cases in children <18 years old [17] with at least 336 deaths.

We now consider the three states that were an exception and whether events occurring in these states might explain the difference in findings. There were two types of events occurring. The first such event, the Sturgis Motorcycle Rally held annually in South Dakota, easily explains the reversal from the usual pattern that we find in South Dakota. The data from South Dakota were from October 23, 2020, and followed the Sturgis Motorcycle Rally where half a million bikers converged on Sturgis between August 7 and August 16, 2020. Dave et al. [18] link a deluge of COVID-19 cases to this event since social distancing and mask-wearing were rare in Sturgis $[19,20]$. The event led to increased cases in South Dakota as well as in other states from where bikers travelled to South Dakota. Using anonymized cell phone data from SafeGraph Inc., the authors traced smartphone pings from non-residents and indicating that visitors came to Sturgis from all parts of the US, including states that recently experienced surges in COVID-19 cases. The attendees opened themselves up to infection at this super-spreader event, and then contributed to increased case counts in their home states when they returned home. These attendees were mostly adults who would be more likely to come into contact with 
medRxiv preprint doi: https://doi.org/10.1101/2021.07.06.21260112; this version posted July 8, 2021. The copyright holder for this preprint (which was not certified by peer review) is the author/funder, who has granted medRxiv a license to display the preprint in perpetuity. It is made available under a CC-BY-NC 4.0 International license .

other adults rather than adolescents and youth, thereby increasing the number of cases in adults, including older adults.

This explanation is bolstered by prior data on South Dakota from Summer 2020, i.e., from September $4^{\text {th }}$, when the prevalence of COVID-19 in 10-19-year-olds was significantly greater than it was in $>60$-year-olds $(\mathrm{p}<0.00001)$. Similarly, the proportion of cases observed to expected, was significantly greater in 10-19-year-olds than in those $60+(\mathrm{p}<0.00001)$. Six weeks later, as more cases from the Sturgis event developed, there was no longer a significant difference in the prevalence between the adolescents and older adults.

As for Pennsylvania and Michigan, the operative event that may have led to a reversal in the expected pattern of results was the Trump rallies. Both Pennsylvania and Michigan were important for Trump to win the election and were the sites of many Trump rallies, which were known to be largely without masking and social distancing. In Pennsylvania, the data are from October 30. From August through October $30^{\text {th }}$, between Trump and his son Don Jr., there were 15 Trump rallies held in Pennsylvania. Trump held nine of these rallies in Pennsylvania [21]:

Old Forge, Pa. (August 20, 2020); Latrobe, Pa. (September 3, 2020); Moon Township, Pa. (September 22, 2020); Somerset County Sept 11, 2020); Middletown, Pa. (September 26); Johnston, Pa. (October 13, 2020); Erie, Pa. (October 20, 2020); Allentown, Pa. (October 26, 2020); Lititz, Pa. (October 26, 2020); and Martinsburg, Pa. (October 26, 2020). Don Jr. held an additional 6 of the Pennsylvania rallies [22-26] at the following locations on the following dates: Blue Ridge Sportsman Club outside Harrisburg, Pa. (Sept. 16, 2020); Roxbury Park Bandshell, Johnstown, Pa. (September 23, 2020); Nittany Valley/Centre County, Pa. (October 19, 2020); Blair County, Pa. (October 19, 2020); York Springs, Pa. (October 30, 2020); Ambridge, Pa. (October 30, 2020). 
medRxiv preprint doi: https://doi.org/10.1101/2021.07.06.21260112; this version posted July 8, 2021. The copyright holder for this preprint (which was not certified by peer review) is the author/funder, who has granted medRxiv a license to display the preprint in perpetuity. It is made available under a CC-BY-NC 4.0 International license .

In Michigan, the data are from November 17, 2020, and in the months leading up to the election, Trump and his son Don Jr. held 11 rallies in the state [21]. They were: Freeland, MI 26), Lansing, MI (October 27, 2020), Waterford Township, MI (October 30, 2020), Davison, MI (Don Jr., October 31, 2020), Grand Bay Marine in Traverse City (Don Jr., October 31, 2020), Macomb County (November 1, 2020), Washington, MI (November 1, 2020), Traverse City, MI

261 (November 2, 2020), Grand Rapids, MI (November 2, 2020). These rallies attracted adults, 262 including older adults, rather than adolescents or youth, and with the lack of social distancing and mask wearing, likely added to the caseloads of older adults. Whereas there were also Trump rallies in some of the other sates we examined, there were far fewer of them: There were 6 in Florida, 1 in Oklahoma, 3 in Minnesota, and 6 in Wisconsin [21] by the dates for the COVID19 tabulated state data, which are 11/12/2020, 10/22/2020, 10/23/2020, and 10/23/2020,

267 respectively. The confluence of the two factors noted-the Sturgis motorcycle super-spreader 268 event and the Trump rallies - likely inflated the number of cases in the older adults. strain parallels the recent findings of the REACT-1 (REal-time Assessment of Community

271 Transmission-1) UK study at Imperial College London for the delta variant. The findings

272 indicate a five-fold higher positivity rate among 5-12-year-olds and youth 18-24 than among 273 older adults, ages 65+ [27]. The findings are being interpreted to mean that youth are driving the 274 UK surge with regards to the delta variant [28]. However, our findings indicate that the high 275 prevalence in adolescents and youth is not a novel phenomenon and was present with the wild276 type strain in our previous study and in the current one. One reason the UK study found a five277 fold difference in positivity which is greater than ours may be that their study was conducted 
278 after vaccinations had been ongoing in the UK for many months for older adults, which would

279 drive down the positivity in that cohort. Our study in the US was conducted prior to the

280 availability of vaccinations, and may be the reason the difference in prevalence between the

281 adolescents/youth vs. older adults was less pronounced.

282 Our finding of the high prevalence of COVID-19 in adolescents and youth in the U.S., taken

283 together with the high virulence and high transmissibility of the delta variant currently

284 circulating in the US, should be considered in any decision about masking in these groups,

285 especially in those under 12, for whom vaccinations are not yet available.

\section{CONCLUSIONS}

287 The findings of high prevalence of COVID-19 and the other prevalence-related measure in

288 adolescents and youth in the U.S. are consistent with our earlier findings in the Summer of 2020.

289 Our findings for the wild-type strain of SARS-CoV-2, are also consistent with the findings of the 290 ongoing REACT-1 study being conducted in the UK with the delta variant. The disparity in 291 prevalence occurs even with the wild-type SARS-CoV-2 lineage, although the disparity between

292 the age groups is not as pronounced. The lower disparity may be the result of our study

293 occurring before vaccinations were available, whereas the UK study took place after months of 294 vaccinating older adults. 
medRxiv preprint doi: https://doi.org/10.1101/2021.07.06.21260112; this version posted July 8, 2021. The copyright holder for this preprint (which was not certified by peer review) is the author/funder, who has granted medRxiv a license to display the preprint in perpetuity. It is made available under a CC-BY-NC 4.0 International license.

\section{REFERENCES}

296

297

298

299

300

301

302

303

304

305

306

307

308

309

310

311

312

313

314

315

316

317

318

319

320

321

322

323

324

325

326

327

328

329

330

331

1. Dong, Y., Mo, X., Hu, Y., Qi, X., Jiang, F., Jiang, Z., et al. Epidemiological characteristics of 2143 pediatric patients with 2019 coronavirus disease in China. Pediatrics. 2020 June; 145: e20200702; DOI: https://doi.org/10.1542/peds.2020-0702

2. Lu X, Zhang L, Du H, Zhang J, Li YY, Qu J, Zhang W, Wang Y, Bao S, Li Y, Wu C, Liu H, Liu D, Shao J, Peng X, Yang Y, Liu Z, Xiang Y, Zhang F, Silva RM, Pinkerton KE, Shen K, Xiao H, Xu S, Wong GWK; Chinese Pediatric Novel Coronavirus Study Team. SARS-CoV2 Infection in Children. N Engl J Med. 2020 Apr 23;382:1663-1665. doi: 10.1056/NEJMc2005073.

3. Bi, Q., Wu, Y., Mei, S., Ye, C., Zou, X., et al. Epidemiology and transmission of COVID-19 in 391 cases and 1286 of their close contacts in Shenzhen, China: a retrospective cohort study. Lancet Infect. Dis. 2020; https://doi.org/10.1016/S1473-3099(20)30287-5

4. Zhang, J., Litvinova, M., Liang, Y., Yan Wang, Y., Wei Wang, W. et al. Changes in contact patterns shape the dynamics of the COVID-19 outbreak in China. Science. 2020; 368: 14811486. DOI: $10.1126 /$ science.abb8001

5. Geliebter, A., Rumain, B., \& Schneiderman, M. Re: Changes in contact patterns shape the dynamics of the COVID-19 outbreak in China. Science. 2020 June 23. Available from: https://science.sciencemag.org/content/early/2020/05/04/science.abb8001/tab-e-letters

6. Kuchar, E., Załęski, A., Wronowski, M. et al. Children were less frequently infected with SARS-CoV-2 than adults during 2020 COVID-19 pandemic in Warsaw, Poland. Eur J Clin Microbiol Infect Dis 2020. (https://doi.org/10.1007/s10096-020-04038-9)

7. de Lusignan S, Dorward J, Correa A, Jones N, Akinyemi O, Amirthalingam G, et al. Risk factors for SARS-CoV-2 among patients in the Oxford Royal College of General Practitioners Research and Surveillance Centre primary care network: a cross-sectional study. Lancet Infect Dis. 2020; 20:1034-1042. (doi: 10.1016/S1473-3099(20)30371-6).

8. Viner, RM, Mytton, OT, Bonell, C., Melendez-Torres, GJ, Ward, JL, Hudson, L et al. Susceptibility to and transmission of COVID-19 amongst children and adolescents compared with adults: a systematic review and meta-analysis. JAMA Pediatr. Published online September 25, 2020. doi:10.1001/jamapediatrics.2020.4573

9. Davies, N.G., Klepac, P., Liu, Y., Prem, K., Jit, M., et al. Age-dependent effects in the transmission and control of COVID-19 epidemics. Nat Med. 2020 Published June 16. https://doi.org/10.1038/s41591-020-0962-9

10. Rumain B, Schneiderman M, Geliebter A. (2021) Prevalence of COVID-19 in adolescents and youth compared with older adults in states experiencing surges. PLOS ONE. 16(3):e0242587.

11. New York Times. COVID in the U.S.: Latest Map and Case Count. Available from https://www.nytimes.com/interactive/2020/us/coronavirus-us-cases.html 
medRxiv preprint doi: https://doi.org/10.1101/2021.07.06.21260112; this version posted July 8, 2021. The copyright holder for this preprint (which was not certified by peer review) is the author/funder, who has granted medRxiv a license to display the preprint in perpetuity. It is made available under a CC-BY-NC 4.0 International license .

12. CDC. (Jan. 28, 2021). "Science Brief: Emerging SARS-CoV-2 Variants." https://www.cdc.gov/coronavirus/2019-ncov/science/science-briefs/scientific-briefemerging-variants.html [Accessed June 25, 2021].

13. Mossong J, Hens N, Jit M, Beutels P, Auranen K, Mikolajczyk R, et al. Social Contacts and Mixing Patterns Relevant to the Spread of Infectious Diseases. PLoS Med. 2008; 5: e74. https://doi.org/10.1371/journal.pmed.0050074

14. Wu Z, McGoogan JM. Characteristics of and Important Lessons From the Coronavirus Disease 2019 (COVID-19) Outbreak in China: Summary of a Report of 72 $\square 314$ Cases From the Chinese Center for Disease Control and Prevention. JAMA. 2020; 323:1239-1242. doi:10.1001/jama.2020.2648

15. CDC. COVID-19 Response Team. Coronavirus Disease 2019 in Children - United States, February 12-April 2, 2020. MMWR Morb Mortal Wkly Rep. 2020 Apr 10;69:422-426. doi: 10.15585/mmwr.mm6914e4.

16. CDC. COVID-19 Case Surveillance Public Use Data Profile. Available from https://data.cdc.gov/Case-Surveillance/COVID-19-Case-Surveillance-Public-Use-DataProfile/xigx-wn5e [Retrieved October 09, 2020].

17. American Academy of Pediatrics. Children and COVID-19: State Data Report, A joint report from the American Academy of Pediatrics and the Children's Hospital Association. Version:6/24/21. COVID-19 and Age. https://services.aap.org/en/pages/2019-novelcoronavirus-covid-19-infections/children-and-covid-19-state-level-data-report/[Accessed June 25, 2021].

18. Dave, D., Friedson, A.I., McNichols, D. \& Sabia, J.J. (2020). "The Contagion Externality of a Superspreading Event: The Sturgis Motorcycle Rally and COVID-19." Center for Health Economics \& Policy Studies, San Diego State University, Working Paper No. 2020901, Sep. 5, 2020. https://cheps.sdsu.edu/docs/Contagion_Externality_Sturgis_Motorcycle_Rally_9-520_Dave_et_al.pdf

19. Groves, Stephen (2020, August 7). "Harleys everywhere, masks nowhere: 80th Sturgis Motorcycle Rally draws thousands." The Chicago Tribune.

20. Walker, Mark (2020, August 7). "If we get it, we chose to be here': Despite virus, thousands converge on Sturgis for huge rally." The New York Times.

21. Wikipedia (2021). "List of post-2016 election Donald Trump rallies." https://en.wikipedia.org/wiki/List_of_post2016_election_Donald_Trump_rallies\#2020_campaign_rallies. [Accessed June 3, 2021.]

22. Wenner, D. (Sept.16, 2020). "Donald Trump Jr. goes on the attack during Dauphin County stop." https://www.pennlive.com/news/2020/09/donald-trump-jr-takes-attack-dog-roleduring-dauphin-county-stop.html_[Accessed June 3, 2021.] 
medRxiv preprint doi: https://doi.org/10.1101/2021.07.06.21260112; this version posted July 8, 2021. The copyright holder for this preprint (which was not certified by peer review) is the author/funder, who has granted medRxiv a license to display the preprint in perpetuity. It is made available under a CC-BY-NC 4.0 International license .

23. Slusser, T. (September 23, 2020). "Donald Trump Jr. at Roxbury Park Bandshell | Johnstown, Pa." The Tribune-Democrat. https://www.tribdem.com/pennsylvania/donaldtrump-jr-at-roxbury-park-bandshell-johnstown-pa/video 39d7a4c8-fe00-11ea-bfc653c6ecf65a4a.html_[Accessed June 3, 2021.]

24. Pallotto, B. (October 19, 2020). "Donald Trump Jr. to return to Centre County for campaign rally" Centre Daily Times. https://www.centredaily.com/news/politicsgovernment/election/article246558018.html[Accessed June 3, 2021.]

25. www.ydr.com (October 30, 2020) "Donald Trump Jr.: 'I've had more blue-collar jobs than Joe Biden"” York Daily Record https://www.ydr.com/videos/news/2020/10/30/donaldtrump-jr-speaks-during-maga-event-adams-county/6089353002/ [Accessed June 3, 2021.]

26. Cassesse, S. (October 30, 2020). "Donald Trump Jr., Sean Parnell and Ted Nugent Headline Rally in Beaver County." KDKA 2CBSPittsburgh. https://pittsburgh.cbslocal.com/2020/10/30/donald-trump-jr-sean-parnell-and-ted-nugentheadline-rally-in-beaver-county/ [Accessed June 3, 2021.]

27. GOV.UK. Department of Health and Social Care. (June 2021) "Independent Report: REACT-1 study of coronavirus transmission: June 2021 final results." https://www.gov.uk/government/publications/react-1-study-of-coronavirus-transmissionjune-2021-final-results/react-1-study-of-coronavirus-transmission-june-2021-final-results

28. NBC "Today" Show (June 22, 2021). "Dr. Anthony Fauci: Delta variant is the greatest threat to eliminating COVID-19," https://www.youtube.com/watch?v=Wqtc5HO-L9I[Accessed June 24, 2021.] 